\title{
SOCIAL JUSTICE AND WATER FOR ALL: CONSTRUCTING A LOCAL LEGAL FRAMEWORK FOR A GOOD GOVERNANCE
}

\author{
Ady Setiawan \\ Doctorate Program of Law, \\ University of 17 Agustus 1945 Semarang, Indonesia \\ Yos Johan Utama \\ Faculty of Law, Diponegoro University, Indonesia
}

Edy Lisdiyono

Faculty of Law, University of 17 Agustus 1945 Semarang, Indonesia

\begin{abstract}
Fulfilling the needs of water is very important in people's lives because water has become a basic need and part of human rights. Conditions that often arise in the field are the problems related to the water quality, the service coverage, the continuity and the commercial. This research aims to develop the concept of regulation in fulfilling the needs of drinking water for equitable communities through solutions to the problem of the community access rights to get the decent clean water quality, the measurable quantities, and the service processes that do not differentiate the community capacity. This research method is a qualitative narrative with the empirical juridical analysis technique, illustrating the social and legal realities in several cities or districts in Indonesian province, and try to understand and explain the logic of logical interconnection between subjects in society that reveals the relationship between laws that are considered fair, or vice versa. The concept of Local Government in fulfilling the needs of drinking water for the community must be fair, comprehensive, and sustainable. However, on the other hand, people often get conditions which are not ideal in the form of water rights and protection services. This research discovers that efforts are needed to develop the concept of local government responsibility by making an ideal and holistic law in the spirit of equity and justice, taking into account the interests of the preservation of water resources themselves. The reconstruction of the concept of regulation of the responsibility of local governments, in fulfilling the needs of drinking water for the community, is needed because there has been a change in water as an economic value, and not human rights anymore.
\end{abstract}

Keywords: Equitable, The Needs of Drinking Water, Local Government. 
Cite this Article: Ady Setiawan, Yos Johan Utama, Edy Lisdiyono, Social Justice and Water for all: Constructing a Local Legal Framework for a Good Governance. International Journal of Civil Engineering and Technology 11(1), 2020, 209-216.

http://iaeme.com/Home/issue/IJCIET?Volume=11\&Issue $=1$

\section{INTRODUCTION}

Water is the most significant liquid on Earth, and plays a very important role in maintaining the life of organisms. Humans have been dependent on water since eternity. In the effort, humans have developed water resources to ensure reliable water supplies for their domestic, industrial, and agricultural needs. In general, the development of water resources refers to the collection of river flow, rainfall, or groundwater to meet human needs (Dixit, 2019). The role of clean water in the community life, which ranks very important, is illustrated in the Figure 1 below which explains that clean water is an important part of economic and political growth, in a hierarchy, so that it requires legal arrangements, both community and institutional (Schlör, et al., 2018).

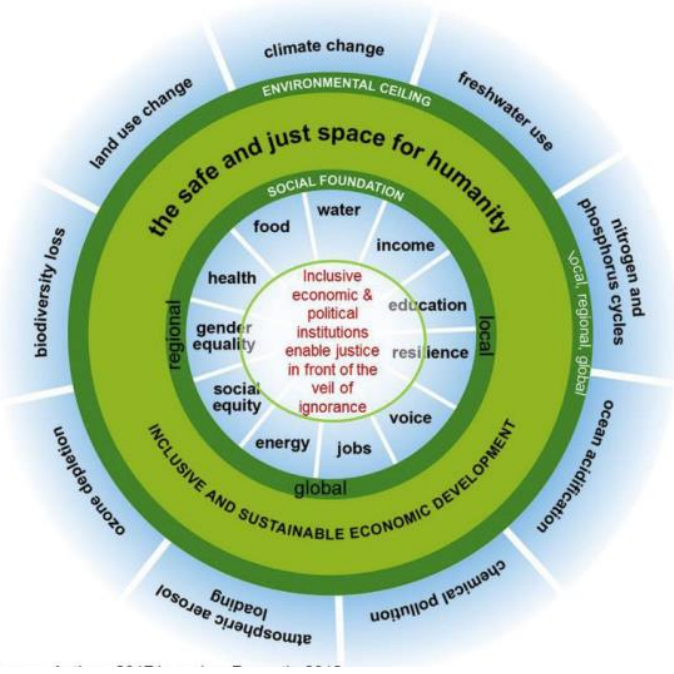

Figure 1. Doughnut Economy; Source: Schlör, 2018.

The issue of justice has become an important part of the debate over water governance that has taken place in various countries. An example of a research case which has occurred in Myanmar, that is a contested water management plan for five large water-powered dams in politically contested areas on the Salween River main stream, including the Hatgyi Dam in Hpa An District, Karen State (Bright, 2019). This is very different from what happens in Indonesia where the Regional Government has the right to autonomy over its natural resources.

The state, as the one that is responsible for people's prosperity, should have guaranteed the people's rights to meet the needs of clean water. The availability of clean water intended for the public is mandated in the 1945 Constitution of the Republic of Indonesia, Article 33, verse (3), stating: "The earth and the water, and the natural resources contained therein, are controlled by the state, and used for the greatest prosperity of the people." The government has provided public services to the community long before the consumer protection efforts exist. It all is done to provide services to consumers, and to make sure that they can use these public facilities at a low cost. In fact, there are still many consumers who have not gained satisfaction in using public services, even though the government has changed its status to become a monopoly service provider (Sukmaningsih, 1997). 
The concept of local government legal responsibility is to guarantee the availability of raw water for the operation of the Drinking Water Supply System (SPAM) for equitable communities. The legal responsibilities of local governments in ensuring the availability of raw water for the implementation of SPAM for the community must reflect substantial justice. In realizing the availability of drinking water for the community based on five pillars, namely democracy, the rule of law, the human right protection, social justice, and anti-discrimination. The Regional Government must actively seek prosperity and act fairly which can be felt by the entire community equally and in balance, not the welfare of certain groups. The use of the welfare state theory needs to be supported by the regulation of legal responsibilities of regional governments in ensuring the availability of raw water for the implementation of SPAM for equitable communities.

So far there has been an injustice in the regulation of local government responsibility in fulfilling drinking water needs for the community. The Regional Government relinquishes this responsibility, leading to a private monopoly on water management. Negligence of responsibility is carried out through the right to use mechanism. In the Law on Water Resources (UU SDA), Article 9, verse 1, states that water use rights can be granted to individuals or business entities with permission from the Government or Regional Government in accordance with their authority.

\section{SIMPLIFICATION AND REGULATORY REFORM IN REGIONAL AUTONOMY ERA}

Based on the description of the simplification and regulatory reform in the regional autonomy era in the background above, it can be formulated that the problem to be investigated is the occurrence of problems regarding the role of local governments in fulfilling the needs of drinking water for the community where the local government responsibilities are needed in the era of regional autonomy, including the comparison of the concept of regulation in fulfilling the needs of drinking water that has not been just and building a just concept. This research method uses an empirical juridical approach, which is carried out hermeneutically or dialectically through the interaction of researchers with those studied. Researchers' decisions also shape the process and the results of research. If there is an interaction between the researcher and the object of research, so the research results are created or constructed together. This research is examined using the socio-legal study that emphasizes making descriptions of social and legal realities, as well as trying to understand and explain the logic of logical connection between the two (Rahardjo, 1980). The socio-legal study in the actual realistic realm is expected to be known, whether the positive law that exists, or the law that was born from the patterns of relations between subjects in this society, is a law that is fair or not.

\section{STUDY OF DRINKING WATER FULFILLMENT}

\subsection{Roles of Local Governments in Fulfilling Drinking Water Needs}

Clean water has become a very basic human need, and refers to the 1945 Constitution, Article 33, verse (3), asserting that the Regional Government has obligations and responsibilities, one of which is to manage the water used for the greatest prosperity of its people, and in line with the enactment of Law Number 7 of 2004 concerning Water Resources. One of the authorities and responsibilities of the Regional Government is to fulfill the minimum daily basic needs for water for the people in the area, and to maintain the effectiveness, efficiency, quality, and order. Water is an inseparable part of human rights itself. These human rights "implicitly" in the International Covenant "ECOSOC" concerning economic, social, and cultural rights, especially in Law Number 7 of 2004 concerning Water Resources, Article 11 and Article 12, 
which are clarified in Act Number 11 of 2005 concerning Ratification of the International Covenant on Economic, Social, and Cultural Rights. In Article 11, discussing the right to enjoy the highest physical and mental health standards that can be achieved, this means ensuring that the right or an adequate standard of living is the state's obligation to fulfill it.

The study in Law Number 11 Year 2005, Article 12, regarding the right to the spiritual and physical health, which is one of the most important elements in it is a matter of the environmental health that is closely connected to water. Explicitly that water is seen from any perspective can never be separated from life, even water is the life itself (Krhua, 2005). Consumer rights and obligations have been regulated in Act Number 8 of 1999 concerning Consumer Protection. Furthermore, the right exists if the obligation must be fulfilled. Rights and obligations must run in a balanced manner so as to create a just and prosperous society (Sinaga, 2009). Paying attention to the right to water as a human right, and guarantees regarding the rights of consumers, is an effort that must be done, especially the government. This is to prevent the emergence of obstacles, especially in preventing problems that harm the customer. In the Law on Human Rights and Law Number 8 of 1999 concerning Consumer Protection, it is expected to provide legal certainty in fulfilling the needs of clean water carried out by the Local Drinking Water Company (PDAM). Other provisions are emphasized in Law Number 7 of 2004, Article 5, concerning Water Resources which states "The state guarantees the right of everyone to get water for basic daily needs to meet their healthy, clean and productive lives." must carry out various efforts to ensure the availability of water for everyone who lives, which is a joint responsibility among stakeholders, including ensuring everyone's access to water. The PDAM, as a local authority that is obliged to carry out the function of public services and to prosper the community, should have carried out their responsibilities in accordance with the regulation of the supply of drinking water that has the objective to (Wright-Contreras, et al. 2019):

(i) Providing services to the community in accordance with the scope of their business; (ii) Contribute to regional own-source revenue; and (iii) Participating in and enhancing the regional economy.

\subsection{Concept of Unequitable-yet Regional Government Regulation}

Water is one of the resource categories controlled by the State, as mandated in the 1945 Constitution, Article 33, Verse 3, states that water is controlled by the state, and is fully utilized for the prosperity of the people. As implementing the basic idea of the constitution, the state has provided the Law on Water Resources (UUSDA) 2004. However, that Act has betrayed its enthusiasm to carry out the mandate of the constitution. Some articles in the Act have become the foundation of the birth of several government regulations that have been considered to betray the spirit of the constitution.

The state is responsible for controlling water for the greatest prosperity of the people. In its implementation so far, the country has lagged far behind the private sector in fulfilling the needs of household drinking water. The responsibility of conserving water resources as stipulated in Law Number 32 Year 2009, Article 71, concerning Environmental Protection and Management, states that the Minister of the Environment, Governor, or Regent/Mayor, in accordance with their authority must supervise the observance of the people in charge businesses and/or activities on the provisions stipulated in the applicable laws and regulations.

The implementation of the provisions in UUSDA, paragraph (5), Article 21, then in 2008 the rules referred to were stipulated through Government Regulation (PP) Number 42 of 2008 concerning Water Resources Management (SDA). In Paragraph 5 Protection of Water Sources, in Relation to Land Development and Utilization Activities in Water Sources, it is stated that: Article 55 paragraph (1) Protection of water sources in relation to development 
activities and land use at water sources is carried out through regulation of development activities and/or land use in water sources. A regulation of the responsibilities of the Regional Government in the service of drinking water for the community by making an ideal and holistic law with the spirit of equity and justice, not merely towards the target of economic growth, but by considering the interests of the preservation of water resource itself (Huang, 2008). In making an ideal and holistic law, it is necessary to make improvements and rearrange the grand design of the national water source management system. The way to do this is by building the mindset of the community and all stakeholders, that water is not an unlimited natural source. The concept of state responsibility in fulfilling the drinking water needs for unequitable citizens has been carried out by the House of Representatives and the Government, which has created the UU SDA 2004 Law, then followed by the making of a Government Regulation which completely ignored the record of the Constitutional Court's Decision on a judicial review of the Decision Number 058-059-060-063/PUU-II/2004 and Number 008/PUU-III/2005.

According to the author, the cancellation of several articles in UUSDA should not completely invalidate its validity, only because four articles resulted in the inclusion of the private sector to manage water resources. It should be enough to make changes to the articles that are considered problematic. Given that it requires a large cost and time that is not short to prepare a draft until the ratification of a law. In addition, the articles which are not problematic and the regulations for its implementation can still be used and needed. A review of the provisions and regulations on the implementation of the responsibility for conserving water resources is absolutely necessary, so that there is no vacuum in the law as it is today.

Under the UUSDA which has encouraged the state to relinquish responsibility, the relinquishment of that responsibility results in a private monopoly over water management. The private monopoly causes the value of water to become commercial. The Decision of the Constitutional Court (MK) is a new hope for improving the water management.

\section{ESTABLISHING EQUITABLE SOCIETY}

All this time, UUSDA has spoiled the country to neglect, and finally relinquished the responsibility for the water management. Such negligence of responsibility is carried out through the right to use mechanism. In UUSDA Article 9, paragraph 1, states that the right to use water business can be given to individuals or business entities with permission from the Government or regional government in accordance with their authority. Furthermore, UUSDA Article 40, paragraph 4, states that cooperatives, private business entities, and the public can participate in the development of the Drinking Water Supply System (SPAM). In granting participation to the private sector above, it turns out that in practice it is distorted by the emergence of privatization. The meaning of privatization in the opinion of the figures is essentially the reduction of government involvement or intervention in direct economic activities. The role of government is to limit themselves to carry out tasks that cannot be carried out by the market, such as providing defense and security (Ika \& Samosir, 2002).

\subsection{Stop on Private Monopolies}

The responsibility of the State is the fulfillment of water supply for the community, but what happens is that it forgets its responsibility. One reason for the constraints is the budget, budget constraints; the state is unable to provide water for its people. The state, in the water management, initially devoted to the State-Owned Enterprises (Central and Regional), but was suddenly allowed to be carried out by the private sector as well (H \& P, 2003; G \& J, 2016). The case of PT. Tirta Investama Klaten, where the drinking water crisis occurred, has been felt by the residents of several districts around the factory, namely Ceper District, Pedan 
District, and Delanggu District. The spokeswoman of PT. Tirta Investama Klaten, Fainta Susilo Negoro, acknowledges that the water taken was 23 liters per second at the start of the operation, and now it is 30 liters per second. Although the company provided compensation increases from IDR 1 to IDR 5.39 per liter for each siphoned water, yet the drought has become increasingly rampant due to the water crisis, and even causing other adverse impacts such as conflicts between farmers, or residents with farmers fighting for water.

\subsection{Stop Commercialization of Water}

The water privatization has turned water, which should have social value, into economics. Water, as a public (social) commodity which has multiple functions and multiple interrelated scales, must be managed and utilized according to its cycle. The use of water use rights at all levels (whether for individual, group or global needs) cannot change its existence from public goods to private goods. Therefore, it is not appropriate to exploit and trade it freely and more. The commercialization paradigm has been run by a Bottled Drinking Water company (AMDK). The government is very difficult to control the price of bottled water that has been set by private companies, although there is a pretext that the costs to be paid by the community are only service costs. During this time, the facts in the field are very contrary to what is conveyed by the UUSDA, Article 80, verse 1 , states that "The users of water resources, in order to meet their daily basic needs and for people's agriculture, are not burdened with the cost of water resource management services."

Based on the 1945 Constitution, Article $28 \mathrm{H}$, verse 1, states that everyone has the right to live physically and mentally prosperous, to settle in, and to have a good and healthy living environment, and also to receive health services. This article can be interpreted as an obligation by the state to provide water fulfillment for its citizens, which reflects three aspects as the basic element of the right to water that must be met. The three basic elements, borrowing the terms of Majda, namely: availability, quality and accessibility, including physical accessibility, affordability or economic accessibility, non-discrimination, and information accessibility (Kanakoudis \& Tsitsifli, 2014). It will be very sad in case the fulfillment of human rights depends on purchasing power. This policy through water privatization and protection in UUSDA has proven to open great opportunities for multinational companies to control water sources in Indonesia, so that the public interest will be commercialized by the market law (Rahmadi, 2011).

\section{ESTABLISHING EQUITABLE REGIONAL GOVERNMENT REGULATIONS}

Conceptual conservation of water resources has various meanings. One of the most relevant meanings is the obligation that is borne by someone, everything that must be borne, an obligation that must be carried out. An obligation means the rules that define the obligations and the rights of community members (primary rules). The obligations which is closely related to internal beliefs and motivations will have unpleasant impact if they are not implemented, and conversely, it is expected that such unpleasant impact will not occur if they are implemented. Obligations should continue to be carried out, otherwise, it will lead to sanctions (Rundel and Palma, 2000).

When implementing the water resources conservation, the Regional Government should be able to guarantee the utilization wisely, and guarantee the continuity of their supplies while maintaining the quality and value that cannot be avoided from any business activity by anyone involved, including the business actors and the community. The responsibility of the PDAM for fulfilling the consumers' rights of the PDAM is to distribute clean water to the community in accordance with the clean water quality standards. The distribution of clean 
water is the main thing that becomes the main priority of the implementation of company activities; to distribute the water for 24 hours, with a minimum water pressure of 0.5 bar evenly. The responsibility of the Regional Government can be given by the PDAM by implementing a program to reduce the level of water loss through the Water Activity Management Unit (UPKA), replacement of secondary and tertiary pipes, calibration of customer water meters, as well as holding equipment for detecting leakage, maintenance and checking of water material owned by PDAM; checking is done every month for the pipes that are considered to have sufficient potential and other water material, One Stop Integrated Services (PTSP), District Meter Zone (DMZ), and developing distribution pipelines to the areas that are densely populated and have not been streamed by drinking water. In addition, there are also services for several complaints from customers related to the drinking water service.
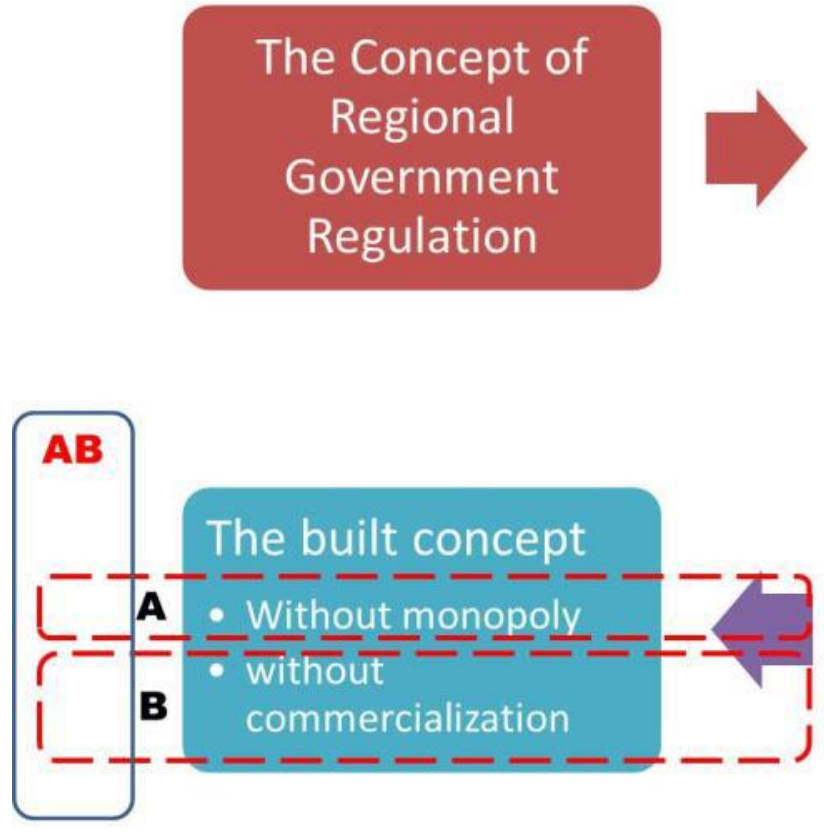
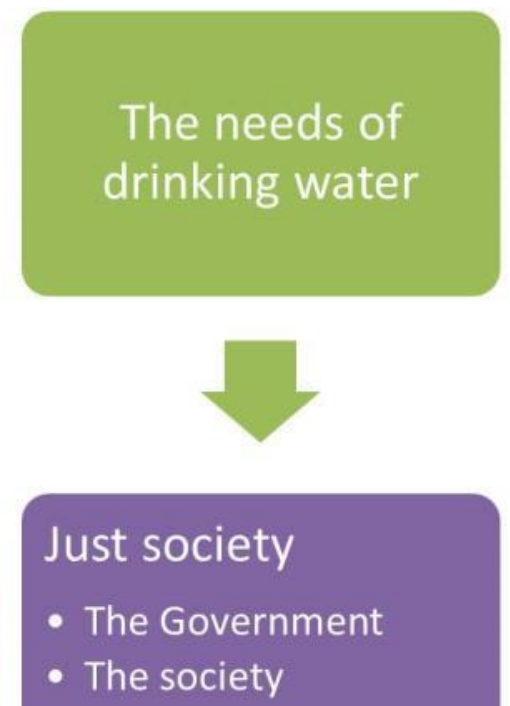

$A B g$ reduced to Built $A B s$

Figure 2. The Chart for the Theory of Fulfilling the Needs of an Equitable Society. Source: Author.

Figure 2 above illustrates a diagram for the theory of fulfilling the community's needs which we call the $A B g$ Reduce to Build Abs Diagram, that is through the reduction of the elements A, namely the monopoly, and B, namely the commercialization in government $(\mathrm{ABg})$, it will be able to grow the element $\mathrm{A}$, namely the economy society, and $\mathrm{B}$, namely the prosperity society, in the (Abs).

\section{CONCLUSION}

The conclusion so far is that the role of the local government, in fulfilling the needs of drinking water for citizens to prosper the community, is naturally in good faith in running its business; in this case, the PDAM strives as much as possible in the management and distribution of water, various efforts that PDAM has made to fulfill the needs of customers/consumers. The concept of local government regulations in fulfilling the needs of drinking water for the community is by involving various elements, namely the Regionalowned enterprises (BUMD), cooperatives, business entities, and the community. The Regional Government in the drinking water services for the community, by making the ideal and holistic laws with the spirit of equity and justice, is not solely aimed at the economic growth, but by taking into account the interest of the preservation of the water resources itself. 
Developing the concept of local government regulations in fulfilling the needs of drinking water for the equitable citizens, which reflects the availability of water for human life and the access to water, becomes a part of human rights. The access to the need for human rights to water requires to be reviewed because several countries, that used to conduct privatization, have begun to conduct the reviews. The privatization of the right to water will open opportunities for discrimination in accessing the need for human rights to water. Privatization will have the consequence of creating conditions for some people to get the good-quality drinking water, while most others find it difficult to access and reach it properly.

\section{REFERENCES}

[1] Bright, S.J. (2019), Rites, Rights, and Water Justice in Karen State: A Case Study of Community-Based Water Governance and the Hatgyi Dam, Springer International Publishing, available at:https://doi.org/10.1007/978-3-319-77440-4_5

[2] Dixit, P. (2019), "Rivers and social justice: adopting an ethical approach to river basin management in India", Indian Law Review, Routledge, Vol. 3 No. 1, pp. 97-115.

[3] G, L \& J, P 2016, 'The optimal scope of the royalty base in patent licensing', J Law Econ, vol 5, no. 1, pp. 45-73.

[4] H, S \& P, T 2003, 'Competitive implications of information technology in the public sector: The case of a city geographic information system', International Journal of Public Sector Management, vol 16, pp. 8-26.

[5] Huang, JHJ 2008, 'Landscape design of urban waterfront'.

[6] Ika, S \& Samosir, AP 2002, 'Analisis Privatisasi Bumn Dalam Rangka Pembiayaan APBN', Jurnal Kajian Ekonomi Dan Keuangan, vol 6, no. 4.

[7] Kanakoudis \& Tsitsifli 2014, 'Doing the Urban Water Supply Job: from Privatization to Remunicipalisation and the Third Pillar of the Performance Based Service Contracts', Water Utility Journal, vol 8, no. 31.

[8] Krhua, T 2005, Kemelut Sumber Daya Air Menggugat Privatisasi Air di Indonesia, LAPERA, Yogyakarta.

[9] Rahardjo, S 1980, Hukum dan Masyarakat, Alumni, Bandung.

[10] Rahmadi, T 2011, Hukum lingkungan di Indonesia, Rajawali Pers, Jakarta.

[11] Rundel, P.W. and Palma, B. (2000), "Preserving the unique puna ecosystems of the Andean Altiplano: A descriptive account of Lauca National Park, Chile", Mountain Research and Development, Vol. 20 No. 3, pp. 262-271.

[12] Schlör, H., Venghaus, S., Fischer, W., Märker, C. and Hake, J.F. (2018), "Deliberations about a perfect storm - The meaning of justice for food energy water-nexus (FEWNexus)", Journal of Environmental Management, Vol. 220, pp. 16-29.

[13] Sinaga, JR 2009, Perlindungan Hukum Terhadap Konsumen Dalam Pelayaan Air Bersih: Studi Pada Masyarakat Kota Medan, Pelanggan PDAM Tirtanadi Cabang Medan, Medan.

[14] Sukmaningsih, I 1997, Dimensi Pelayanan Publik Dalam Masalah Perlindungan Konsumen, Lokakarya Hukum Perlindungan Konsumen Bagi Dosen Dan Praktisi Hukum, Jakarta.

[15] Wright-Contreras, Perkins, Pascual \& Soppe 2019, 'Water operators' partnerships and their supporting role in the improvement of urban water supply in Da Nang', International Journal of Water Resources Development, vol 36, no. 1, pp. 1-26. 